\title{
Developing heat rate and heat capacity measurement instruments of textile waste solution in the textile dyeing process
}

\author{
Valentinus Galih Vidia Putra ${ }^{1 *}$, Endah Purnomosari ${ }^{2}$, Juliany Ningsih Mohamad ${ }^{3}$ \\ ${ }^{1}$ Politeknik STTT Bandung, Bandung, West Java, Indonesia \\ ${ }^{2}$ Politeknik STTT Bandung, West Java, Indonesia \\ ${ }^{3}$ Universitas Nusa Cendana, Kupang, Indonesia
}

*Corresponding Address: valentinus@kemenperin.go.id

\begin{abstract}
Article Info
\section{Article history:}

Received: March 22 $2^{\text {nd }}, 2020$

Accepted: October $14^{\text {th }}, 2020$

Published: October $30^{\text {th }}, 2020$

\section{Keywords:}

Heat rate;

Specific heat;

Textile;

Textile waste.

ABSTRACT

Heat rate and heat capacity are widely used to determine the thermal characteristics, especially for wastewater treatment using electro coagulant. This study aimed to determine the value of heat rate and heat capacity of the waste solution in the textile industry, especially in the dyeing waste, by using a microcontroller device. The method for measuring the specific heat capacity and the textile waste solution's heat rate is based on the principle of the first law of Thermodynamics. Temperature measurements were carried out using a digital temperature sensor type DS18B20. In this research, the heat rate and specific heat of the dyeing solution and mineral water used in the textile industry have been studied. This study uses five types of dyeing waste solution as test solutions, namely green waste solution, orange waste solution, blue waste solution, brown waste solution, and mineral water. This experiment's principle is applying Joule's law by using electrical properties with a microcontroller device used to obtain the rise of temperature data each time in real-time every 2 seconds. Based on this research, it can be concluded that the instrument can be used to measure the heat rate and heat capacity of a textile waste solution. Based on this research, we also found that the specific heat of hard water (Hard water is a kind of water with high mineral content, while soft water is water with low mineral content. Apart from calcium and magnesium ions, the cause of hardness can also be other metal ions as well as bicarbonate and sulfate salts) $(4.19 \pm 0.77) \mathrm{J} /$ gram ${ }^{\circ} \mathrm{C}$ and the specific heat of the four types of waste solution ranged from (3.20 \pm $0.72) \mathrm{J} /$ gram ${ }^{\circ} \mathrm{C}$ to $(6.83 \pm 1.71) \mathrm{J} /$ gram ${ }^{\circ} \mathrm{C}$ and also it was found that the heat rate of hard water is $0,0471^{\circ} \mathrm{C} / \mathrm{s}$ and the heat rate of the four types of waste solution is range from $0,0289^{\circ} \mathrm{C} / \mathrm{s}$ to $0,0617^{\circ} \mathrm{C} / \mathrm{s}$.
\end{abstract}

(C) 2020 Physics Education Department, UIN Raden Intan Lampung, Indonesia.

\section{INTRODUCTION}

Water hardness is the content of certain minerals in the water, generally calcium (Ca) and magnesium $(\mathrm{Mg})$ ions in the form of carbonate salts. Hard water has a high mineral content, while soft water is water with low mineral content. Apart from calcium and magnesium ions, the cause of hardness can also be other metal ions and bicarbonate and sulfate salts. The textile industry's main problem today is the problem of waste that is often found in the process of dying or coloring (Desianne et al., 2017; Giwaa et al., 2012; Hashim et al, 2017; Said, 2002). Textile waste is generally liquid, so there are several methods to eliminate the spectrum of pollutants and wastewater, such as the plasma injection method, the electro coagulant (EC) method, 
and the dielectric discharged method (Amril, 2020; Hashim et al., 2017; Putra et al., 2020; Rusydi et al., 2017; Wakida, et al., 1993). These methods generally use heat from a current movement, which flows in wastewater to break down molecules in the waste. The heat properties of a liquid generally depend on the heat rate and the liquid type's heat capacity. According to some researchers (Fadli et al., 2018; Hashim et al., 2017; Giwaa, et al., 2012; Mouedhen et al., 2008; Yilmaz et al., 2008), the electrocoagulation method (EC) is one of the in-situ methods that directly enter electric current through metal electrodes, and this method has been applied now for eliminating the spectrum of liquid pollutants and wastewater, especially in the textile field. In the textile dyeing and coloring industry, electric energy, hard water, and chemical solutions create some problems in the environment. Furthermore, these issues cause an increase in manufacturing costs (Sathian, et al., 2014). Some researchers (Ridantami et al., 2016; Mouedhen et al., 2008; Hashim et al., 2017; Giwaa et al., 2012) said that although the application of the electrocoagulation method (EC) has been widely used, the efficiency of this method is greatly influenced by the main parameters, such as electrolysis time, voltage and current from the source, and temperature of the waste solution. Therefore, current investigations have been carried out to explore the effect of electrode spacing on the EC method's performance in terms of internal temperature to be able to remove iron from liquids. According to some researchers (Hashim et al., 2017; Simoes-Moreira, 2010; Biesheuvel, 2009; Cengel \& Boles, 2002; Quick et al., 2019; Pogatscher et al., 2016; Cengel \& Boles, 2010; Zhuravlev, 2010; Thomas, 2018; Schick, 2016; Pogatscher, 2014), the need for a real-time heat rate and heat capacity test solution is to obtain a study thermodynamics properties. Some researchers (Abdelhady, 2009; Cengel \& Boles, 2002; Picker et al., 1971) also said that it is necessary to develop a device to measure the properties of the heat rate and heat specific simultaneously in the research of thermodynamics in advance. Several researchers have widely used physics in the textile field (Putra et al., 2020; Ulesova, et al., 2008), who studied the application of physics in textile dyeing, especially in continuous dyeing of wool fabric containing polyamide fiber and modified by plasma glow discharge. Some researchers (Wakida et al., 1998; Wakida et al., 1993; Putra et al., 2019; Putra \& Wijayono, 2019; Putra et al., 2020) have implemented the application of physics in the textile industry, especially in the dyeing process in the textile industry. Putra and Wijayono (2019) apply physics to the modification of mechanical properties using corona discharge plasma technology especially wetting properties that previously used chemical fluids and are not environmentally friendly (because it can cause much liquid waste to modify the wetting properties of the textile material). The application of other physical sciences has been carried out by several researchers (Putra et al., 2019; Ditmars, 1988; Sreejith et al., 2015) who have begun to design heat capacitance test equipment in a solution, but the heat capacitance research does not focus on examining heat rate and heat capacity in some textile wastewater.

Some researchers (Badamasi, 2014; Bramawanto et al., 2019; Putra \& Purnomosari, 2015; Raine et al., 1945; Teruel et al., 2019; Hoffmann et al., 2010; Dean \& Rane, 2013; Kodalkar et al., 2019; Biesheuvel, 2009; Boltshauser et al., 1993; Dean et al., 1987) using a microcontroller as a tool in measuring physical quantities. The rate of movement of charge and friction between charges will cause heat in the solution. Some researchers like (Putra et al., 2019; Sreejith et al., 2015; Salvo et al., 2010) stated that research on heat generated by electrical currents and their thermodynamic properties is an exciting research study to be researched, especially with a microcontroller device. The 
application of current physical technology in the textile industry is generally related to textile waste. In the textile industry, in general, the waste treatment process uses the electro coagulant method by giving a potential difference to the two active and passive electrodes in liquid textile waste (both dyeing and coloring) so that the liquid waste can decompose and change color (becoming more transparent). Some researchers (Putra et al., 2019; Badamasi, 2014; Sreejith et al., 2015) have succeeded in designing a device to determine the heat capacitance, but the research has not studied textile waste solution, especially in the textile dyeing process. In this research, the measurement of the heat rate and the heat capacitance of textile waste solution in the textile dyeing process will be examined using an Arduino microcontroller device with a solution mass, temperature rise time interval, and electrode current rate, and specific specified wire resistance. In determining the heat rate and heat capacitance, knowledge of electricity and thermodynamics is needed better. According to (Halliday et al., 1997; Putra, 2017), in electricity, an electric current is defined as the amount of charge flowing through a cross-section every second.

The electric field strength $(E)$ that appears in the conductor is proportional to the potential difference $\Delta V$ and inversely proportional to the wire's length $(l)$. The greater the potential difference $\Delta \mathrm{V}$ and the cross-sectional area of the conductor $(A)$, the more charge moves (Greiner, et al., 1995). When a metal is electrified, collisions occur due to charge carriers in the metal and electrons. It will generate heat, and the atoms in the metal will move stronger (vibrations of atoms in the metal). It can be understood that the moving $d q$ charge will get additional energy of $d U=d q V$. Joule's Law states the loss of power (dissipation power) in a conductor with resistance $\mathrm{R}$ and current flow $i$. This heat is called Joule heat, where 1 calorie $=4.2$ Joules. Heat is a form of energy where the unit is the joule. The amount of heat required for an object to increase its temperature is very dependent on the heat capacity, $C$, of the material of the object. Specific heat is one of the thermometric properties of objects. For a temperature interval that is not too high, usually, $c$ can be considered constant. If an object has mass $\mathrm{m}$, the specific heat of material $c_{v}$ and the initial temperature is $T_{1}$, increasing the temperature to $T_{2}$.

$\Delta \mathrm{T}$ is the change of temperature of a substance that receives the heat of $\mathrm{Q}$. According to some researchers (Picker et al, 1971; Halliday et al., 1997; Greiner et al., 1995; Putra, 2017), the specific heat of a material can be explained as the amount of heat required by the material to raise the temperature of a mass of one gram by one ${ }^{\circ}$ C. Putra, et al. (2019) and Sreejith, et al. (2015) explained that the heat capacity is a quantity that expresses the amount of heat needed by an object to raise the temperature of an object. The value of specific heat is also used to determine the effect of temperature changes on making coconut shell charcoal (Tirono \& Sabit, 2012). Ackermann (1957) has determined the specific heating value to obtain a considerable value of the number of $\mathrm{H}^{+}$ions and $\mathrm{OH}^{-}$electrolyte solutions. There are several previous studies regarding the measurement of the heat capacity value of a solution. Picker, et al. (1971) have designed a prototype device to measure the heat capacity using a micro calorimetric system. Grolier et al. (1975) have also developed a device that can measure the specific heating value for an organic solution. Some researchers (Halliday, et al.,1997) and (Putra, 2017) said that the resistance $(R)$ that is powered by an electric current $(I)$ would cause a voltage difference $\Delta V$ between the ends means the electrical power.

Some researchers (Rahardjo et al., 2018; Hariyanto et al., 2020; Yumang, et al., 2016; Rerkratn \& Kaewpoonsuk, 2015; Anwar et al., 2017; Suherman et al., 2015) have used a microcontroller and developed a temperature measuring device in real-time, 
but the application of a temperature sensor to measure specific heat and heat rate is still rare. This study appears to determine the value of heat rate and the heat capacity of the textile industry's waste solution, especially in the dyeing waste, by using an Arduino Uno Microcontroller device. Temperature measurements were carried out using a digital temperature sensor type DS18B20. This research aims to obtain the heat rate and heat capacity of various textile wastes and their measurement methods using the microcontroller and determine the measurement of heat capacity and heat rate. The novelty and significance of this research are that a real-time measuring device for heat rate and heat capacity using a microcontroller can be used by academics and researchers to research environmental science and material physics studies in textile waste solutions.

\section{METHOD}

The method for measuring the specific heat capacity and the heat rate of the textile waste solution was based on the principle of the first law of Thermodynamics and refer to the research that has been done by Putra et.al. (2019) to validate the tool as well as the solution used to check the accuracy of the instrument was used pure water which had known the specific value of heat. Based on the first law of thermodynamics, it is said that "If heat is converted into another form of energy or if another form of energy is converted to calories, then the previous energy is always constant and the formula can be seen as written in Equation (1) to Equation (4) (Halliday et al., 1997; Putra et al., 2019)

$$
\begin{gathered}
W=Q \\
i^{2} R t=m \cdot c_{v} \cdot \Delta T \\
\Delta T=\frac{i^{2} R}{m c_{v}} \cdot t \\
\Delta T=v_{h} . t
\end{gathered}
$$

The heat rate, $v_{h}$, can be formulated as Equation (4), and specific heat, $c_{v}$, can be formulated using Equation (5) to Equation (7) as written below:

$$
\begin{gathered}
\Delta T=v_{h} \cdot t=m_{\text {grad }} \cdot t \\
\frac{i^{2} R}{m c}=m_{\text {grad }} \\
c_{v}=\frac{i^{2} R}{m m_{\text {grad }}}
\end{gathered}
$$

We used synthetic dyes, which were artificial dyes from Dyeing Laboratory, Politeknik STTT Bandung, Jawa Barat, Indonesia. In these research methods, it is explained the tools and materials and the procedures used in this study. The tools and materials used in this study can be written, as shown below:

\section{Tools and Materials:}

1. Calorimeter;

2. Heating wire;

3. Temperature Sensor (digital temperature sensor type DS18B20) connected to the microcontroller (Arduino Uno Microcontroller) and computer;

4. Voltmeter and ammeter;

5. Power supply;

6. Slide regulator;

7. Waste solution and hard water (from Dyeing Laboratory Politeknik STTT Bandung, Indonesia).

\section{Procedures:}

1. The value of mineral water heat capacity is determined with a calorimeter for instrument calibration;

2. The calorimeter is filled with water, about half of it;

3. The weight of the calorimeter that has been filled with mineral water is measured;

4. The calorimeter circuit is arranged and tested as shown in Figure 1;

5. The temperature changes are observed with a computer screen (taken by a sensor inside the calorimeter) for 30 minutes with an interval of 2 seconds, and the data can be carried out from the computer. Data retrieved starts when the system temperature has stabilized;

6. Multiple measurements can be retrieved by doing the same steps for the waste solution as steps 1-5; 
7. The method for measuring the specific heat capacity and the textile waste solution's heat rate is based on the principle of the first law of

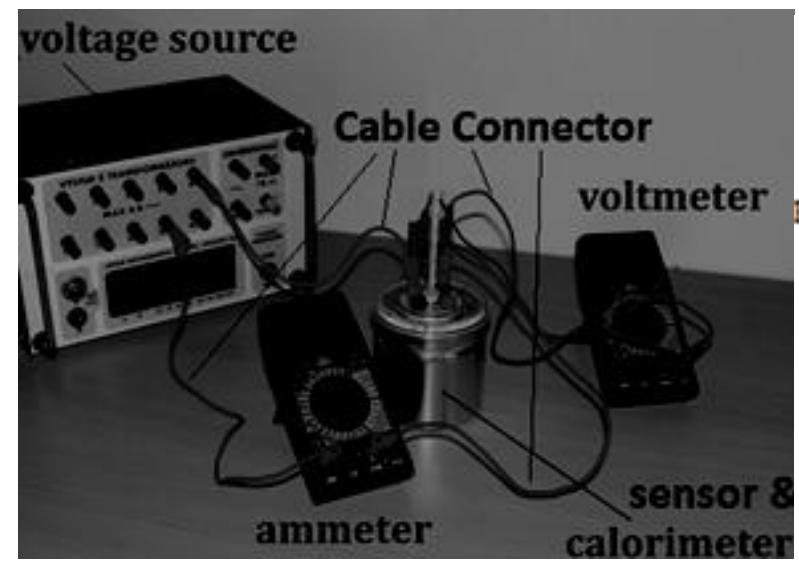

Thermodynamics, and the data is processed by the microcontroller, as shown in Figure 2.

Figure 1. Arrangement of experimental circuit.
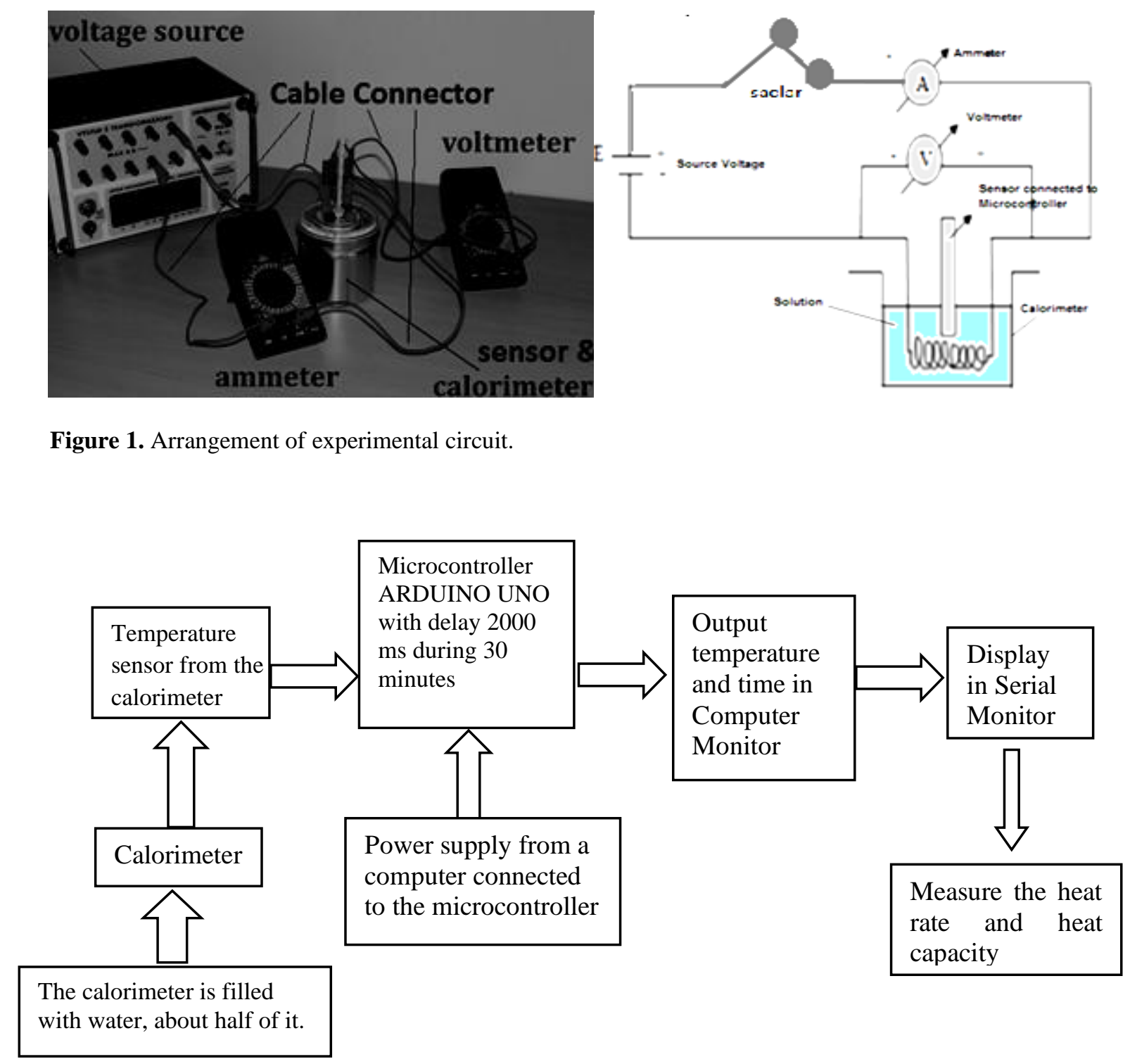

Figure 2. The method for measuring the specific heat capacity and the heat rate of the textile waste solution.

\section{RESULTS AND DISCUSSIONS}

This study aims to determine the value of the heat rate and the heat capacity of the waste solution of the dyeing waste by using a microcontroller device with the scheme as shown in Figure 1 and Figure 2. Temperature measurements were carried out using a digital temperature sensor type DS18B20, and the heat rate and heat specific have been measured as determined by the experiment's result below:

\section{Green Waste (From Dyeing Laboratory Politeknik STTT Bandung, Indonesia)}

The experimental data changes in the temperature of the green dyeing waste solution can be looked at in the heat rate graph, which can be shown in Figure 3. 


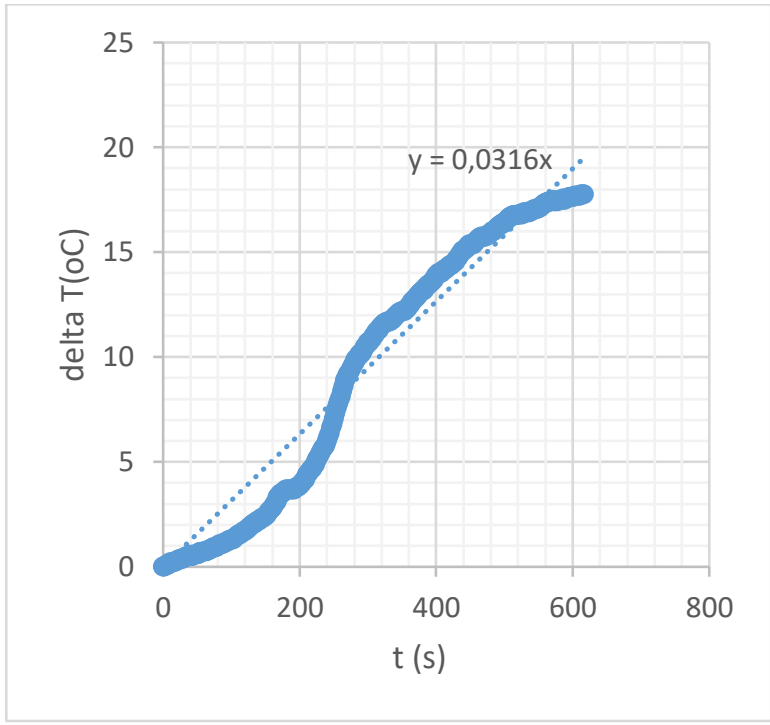

Figure 3. The relationship between time (seconds) to changes in temperature $\left({ }^{\circ} \mathrm{C}\right)$ in a waste solution.

The results of heat capacity and heat rate measurements can be determined as follows for the mass of the solution of $M_{g}=209$ grams, then the heat rate of $v$ is obtained from Figure 3 as written below.

$$
\begin{aligned}
& v=M_{\text {grad }}=0,0316{ }^{\circ} \mathrm{C} / \mathrm{s} \\
& I=2,4 \mathrm{~A} \\
& R=7,17 \Omega \\
& M_{g}=209 \mathrm{gram}
\end{aligned}
$$

Heat rate value and heat capacity are obtained from the slope of the graph of the relationship between temperature changes with time, so it is obtained in Equation (8) and Equation (9))

$$
\begin{aligned}
M_{1}= & \frac{\Delta T_{\text {final }}-\Delta T_{\text {initial }}}{t_{\text {final }}-t_{\text {initial }}} \\
& =\frac{17,75-0}{616-0} \\
M_{2} & =\frac{\Delta T_{\text {final }}-\Delta T_{\text {initial }}}{t_{\text {final }}-t_{\text {initial }}} \\
& =\frac{7,06-0}{250-0} \\
& =0,0282^{\circ} \mathrm{C} / \mathrm{s} \\
=\frac{|0,0288-0,0316|+|0,0282-0,0316|}{2} & \\
\left|\Delta M_{\text {grad }}\right| & =\frac{\left|M_{1}-M_{\text {grad }}\right|+\left|M_{2}-M_{\text {grad }}\right|}{2} \\
& =\frac{|-0,0028|+|-0,0034|}{2} \\
& =0,0031^{\circ} \mathrm{C} / \mathrm{s}
\end{aligned}
$$

$$
\begin{aligned}
& M_{\text {grad }} \pm \Delta M_{\text {grad }}=v \pm \Delta v \\
&=(0,0316 \pm 0,0031)^{\circ} \frac{C}{S} \quad(\mathbf{8}) \\
& C_{v}= \frac{I^{2} R}{m \cdot M_{\text {grad }}} \\
&=\frac{(2,4)^{2} \cdot 7,17}{209 \cdot 0,0316}=6,23 \mathrm{~J} / \text { gram }^{\circ} \mathrm{C} \\
&\left|\Delta C_{v}\right|=\left|\frac{\partial c_{v}}{\partial M_{\text {grad }}} \cdot \Delta M_{\text {grad }}\right| \\
&=\left|\frac{\frac{I^{2} R}{m_{\text {grad }}}}{M_{\text {grad }}} \cdot \Delta M_{\text {grad }}\right| \\
&=\left|\frac{I^{2} R}{m_{\cdot} M_{\text {grad }}{ }^{2}} \cdot \Delta M_{\text {grad }}\right| \\
&=\left|\frac{(2,4)^{2} \cdot(7,17)}{209 \cdot(0,0316)^{2}} \cdot 0,0031\right| \\
&=0 \cdot 613 \frac{\mathrm{J}}{\text { gramo }_{C}}
\end{aligned}
$$

$$
\left(c_{v} \pm \Delta c_{v}\right)=(6,23 \pm 0,61) \frac{J}{\text { gramo }_{C}}
$$

\section{Orange Waste (From Dyeing Laboratory)}

The experimental data changes in the temperature of the green dyeing waste solution can be looked at in the heat rate graph, which can be shown in Figure 4.

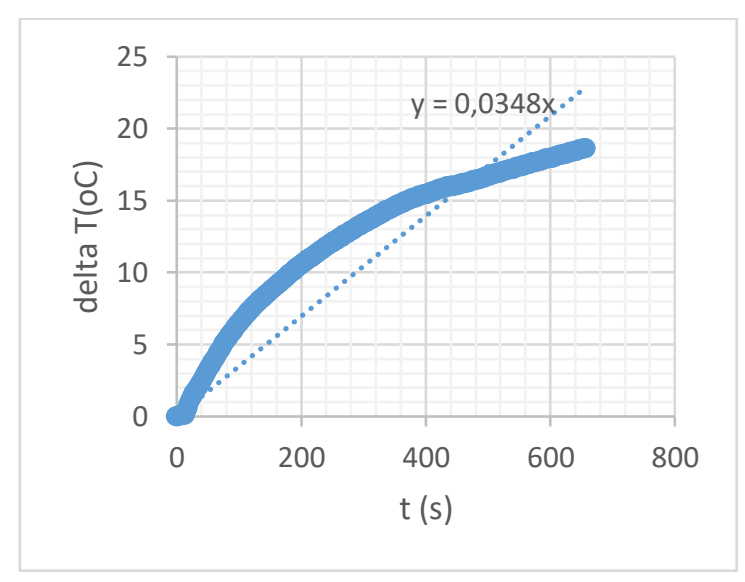

Figure 4. The relationship between time (seconds) to changes in temperature $\left({ }^{\circ} \mathrm{C}\right)$ in a waste solution.

The results of the measurements of heat capacity and heat rate can be determined as follows for the mass of the solution of $M_{g}=$ 209 grams, then the heat rate of $v$ is obtained from Figure 4 as written below (the formula 
can be seen as written in Equation (10) to Equation (13)).

$$
\begin{aligned}
& M_{\text {grad }}=v=0,0348{ }^{\circ} \mathrm{C} / \mathrm{s} \\
& I=2,4 \mathrm{~A} \\
& R=7,17 \Omega \\
& M_{g}=209 \mathrm{gram}
\end{aligned}
$$

Heat rate value and heat capacity are obtained from the slope of the graph of the relationship between temperature changes with time, so it is obtained in Equation (10) to Equation (13).

$$
\begin{aligned}
& M_{1}=\frac{\Delta T_{\text {final }}-\Delta T_{\text {initial }}}{t_{\text {final }}-t_{\text {initial }}} \\
& =\frac{18,63-0}{658-0} \\
& =0,0283^{\circ} \mathrm{C} / \mathrm{s} \\
& M_{2}=\frac{\Delta T_{\text {final }}-\Delta T_{\text {initial }}}{t_{\text {final }}-t_{\text {initial }}} \\
& =\frac{17,63-0}{572-0} \\
& =0,0308^{\circ} \mathrm{C} / \mathrm{s} \\
& \left|\Delta M_{\text {grad }}\right|=\frac{\left|M_{1}-M_{\text {grad }}\right|+\left|M_{2}-M_{\text {grad }}\right|}{2} \\
& =\frac{|0,0283-0,0316|+|0,0308-0,0316|}{2} \\
& =\frac{|-0,0033|+|-0,0008|}{2} \\
& v \pm \Delta v=M_{\text {gradient }} \pm \Delta M_{\text {gradient }} \\
& =0,00205^{\circ} \mathrm{C} / \mathrm{s} \\
& =(0,0348 \pm 0,00205)^{\circ} \mathrm{C} / \mathrm{s} \\
& c_{v}=\frac{I^{2} R}{m \cdot M_{\text {grad }}} \\
& =\frac{(2,4)^{2} \cdot 7,17}{209 \cdot 0,0348} \\
& =5,68 \mathrm{~J} / \operatorname{gram}^{\circ} \mathrm{C} \\
& \left|\Delta c_{v}\right|=\left|\frac{\partial c_{v}}{\partial M_{\text {grad }}} \cdot \Delta M_{\text {grad }}\right| \\
& =\left|\frac{\frac{I^{2} R}{m \cdot M_{\text {grad }}}}{M_{\text {grad }}} \cdot \Delta M_{\text {grad }}\right| \\
& =\left|\frac{I^{2} R}{m \cdot M_{\text {grad }}^{2}} \cdot \Delta M_{\text {grad }}\right| \\
& =\left|\frac{(2,4)^{2} \cdot(7,17)}{209 \cdot(0,0348)^{2}} \cdot 0,00205\right| \\
& =0,334 \mathrm{~J} \operatorname{gram}^{\circ} \mathrm{C} \\
& \left(c_{v} \pm \Delta c_{v}\right)=(5,68 \pm 0,33){\mathrm{J} / \mathrm{gram}^{\circ} \mathrm{C}}^{\circ}
\end{aligned}
$$

\section{Blue Waste (From Dyeing Laboratory)}

The experimental data changes in the temperature of the green dyeing waste solution can be looked at in the heat rate graph, which can be shown in Figure 5.

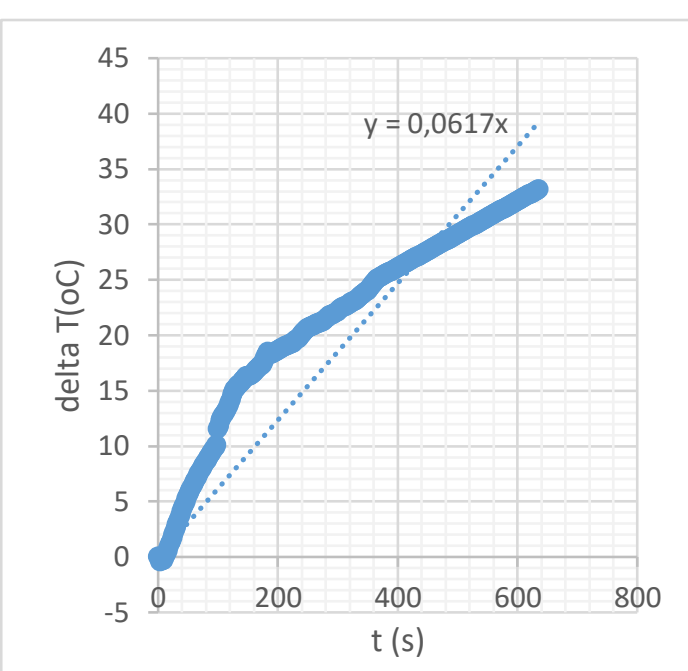

Figure 5. The relationship between time (seconds) to changes in temperature $\left({ }^{\circ} \mathrm{C}\right)$ in a waste solution.

The results of measurements heat rate can be determined as follows for the mass of the solution of $M_{g}=209$ grams, then the heat rate of $v$ is obtained from Figure 5, and the formula can be seen as written in Equation (14) to Equation (15).

$$
\begin{aligned}
& v=M_{\text {grad }}=0,0617{ }^{\circ} \mathrm{C} / \mathrm{s} \\
& I=2,4 \mathrm{~A} \\
& R=7,17 \Omega \\
& v=M_{g}=209 \mathrm{gram} \\
& M_{1}=\frac{\Delta T_{\text {final }}-\Delta T_{\text {initial }}}{t_{\text {final }}-t_{\text {initial }}} \\
& =\frac{33,17-0}{636-0} \\
& =0,052^{\circ} \mathrm{C} / \mathrm{s} \\
& M_{2}=\frac{\Delta T_{\text {final }}-\Delta T_{\text {initial }}}{t_{\text {final }}-t_{\text {initial }}} \\
& =\frac{26,15-0}{402-0} \\
& =0,065{ }^{\circ} \mathrm{C} / \mathrm{s} \\
& \left|\Delta M_{\text {grad }}\right|=\frac{\left|M_{1}-M_{\text {grad }}\right|+\left|M_{2}-M_{\text {grad }}\right|}{2} \\
& =\frac{|0,052-0,0617|+|0,065-0,0617|}{2} \\
& =\frac{|-0,0097|+|0,0033|}{2} \\
& =0,013^{\circ} \mathrm{C} / \mathrm{s}
\end{aligned}
$$


Heat capacity is obtained from the slope of the graph of the relationship between temperature changes with time, so it is obtained, and the formula can be seen as written in Equation (16) and Equation (17)

$$
\begin{aligned}
& M_{\text {gradient }} \pm \Delta M_{\text {gradient }}=(0,0617 \pm 0,013)^{\circ} \mathrm{C} / \mathrm{s} \\
& C v=\frac{I^{2} R}{m \cdot M_{\text {grad }}} \\
& =\frac{(2,4)^{2} \cdot 7,17}{209 \cdot 0,0617} \\
& =3,20 \mathrm{~J} / \mathrm{gram}^{\circ} \mathrm{C} \\
& \left|\Delta C_{v}\right|=\left|\frac{\partial c_{v}}{\partial M_{\text {grad }}} \cdot \Delta M_{\text {grad }}\right| \\
& =\left|\frac{\frac{I^{2} R}{m \cdot M_{\text {grad }}}}{M_{\text {grad }}} \cdot \Delta M_{\text {grad }}\right| \\
& =\left|\frac{I^{2} R}{m \cdot M_{\text {grad }}^{2}} \cdot \Delta M_{\text {grad }}\right| \\
& =\left|\frac{(2,4)^{2} \cdot(7,17)}{209 \cdot(0,0617)^{2}} \cdot 0,013\right| \\
& =0,72 \mathrm{~J} / \mathrm{gram}^{\circ} \mathrm{C} \\
& \left(c_{v} \pm \Delta c_{v}\right)=(3,20 \pm 0,72) \mathrm{J} \mathrm{gram}^{\circ} \mathrm{C}
\end{aligned}
$$

\section{Brown Waste (From Dyeing Laboratory)}

The experimental data changes in the green dyeing waste solution's temperature can be looked at in the heat rate graph, which can be shown in Figure 6.

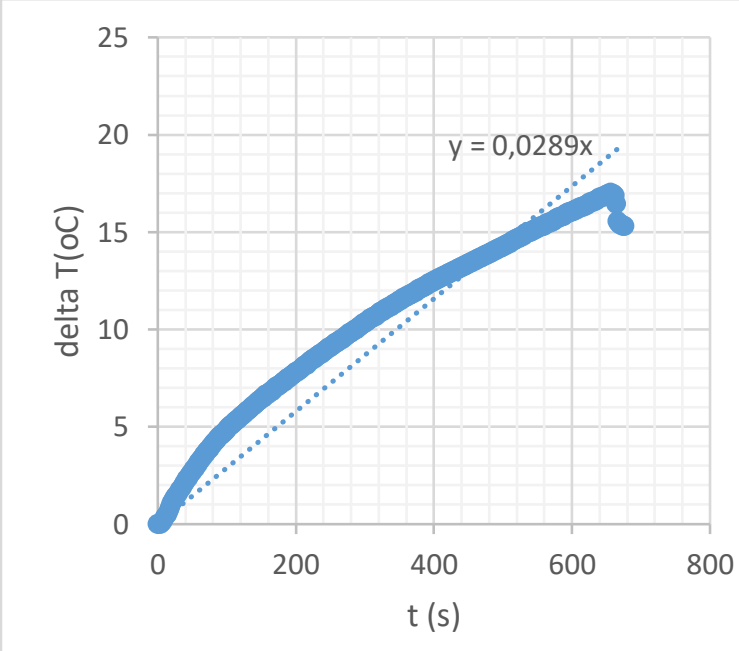

Figure 6. The relationship between time (seconds) to changes in temperature $\left({ }^{\circ} \mathrm{C}\right)$ in a waste solution.
Heat rate value and heat capacity are obtained from the slope of the graph of the relationship between temperature changes with time, so it is obtained in Equation (18) to Equation (22)

$$
\begin{aligned}
& v=M_{\text {grad }}=0,0289^{\circ} \mathrm{C} / \mathrm{s} \\
& I=2,4 \mathrm{~A} \\
& R=7,17 \Omega \\
& M_{g}=209 \mathrm{gram} \\
& c_{v}=6,83 \mathrm{Joule} / \mathrm{gr}^{\circ} \mathrm{C} \\
& M_{1}=\frac{\Delta T_{\text {final }}-\Delta T_{\text {initial }}}{t_{\text {final }}-t_{\text {initial }}} \\
& =\frac{15,32-0}{676-0} \\
& =0,0226^{\circ} \mathrm{C} / \mathrm{s} \\
& M_{2}=\frac{\Delta T_{\text {final }}-\Delta T_{\text {initial }}}{t_{\text {final }}-t_{\text {initial }}} \\
& =\frac{8,76-0}{236-0} \\
& =0,0371^{\circ} \mathrm{C} / \mathrm{s} \\
& \left|\Delta M_{\text {grad }}\right|=\frac{\left|M_{1}-M_{\text {grad }}\right|+\left|M_{2}-M_{\text {grad }}\right|}{2} \\
& =\frac{|0,0226-0,0289|+|0,0371-0,0289|}{2} \\
& =\frac{|-0,0063|+|0,0082|}{2} \\
& =0,00725^{\circ} \mathrm{C} / \mathrm{s} \quad \text { (20) } \\
& M_{\text {gradient }} \pm \Delta M_{\text {gradient }}=(0,0289 \pm 0,00725)^{\circ} \mathrm{C} / \mathrm{s} \\
& c_{v}=\frac{I^{2} R}{m \cdot M_{\text {grad }}} \\
& =\frac{(2,4)^{2} \cdot 7,17}{209 \cdot 0,0289} \\
& =\frac{3,1104}{6,0401} \\
& =6,83 \mathrm{~J} / \mathrm{gram}^{\circ} \mathrm{C} \\
& \left|\Delta c_{v}\right|=\left|\frac{\partial c_{v}}{\partial M_{\text {grad }}} \cdot \Delta M_{\text {grad }}\right| \\
& =\left|\frac{\frac{I^{2} R}{m \cdot M_{\text {grad }}}}{M_{\text {grad }}} \cdot \Delta M_{\text {grad }}\right| \\
& =\left|\frac{I^{2} R}{m \cdot M_{\text {grad }}^{2}} \cdot \Delta M_{\text {grad }}\right| \\
& =\left|\frac{(2,4)^{2} \cdot(7,17)}{209 \cdot(0,0289)^{2}} \cdot 0,00725\right| \\
& =1,71 \mathrm{~J} \mathrm{gram}^{\circ} \mathrm{C} \\
& \left(c_{v} \pm \Delta c_{v}\right)=(6,83 \pm 1,71) \mathrm{J} \mathrm{gram}^{\circ} \mathrm{C}
\end{aligned}
$$




\section{Hard Water (From Dyeing Laboratory)}

The results of experimental data changes in the temperature of the green dyeing waste solution can be looked at in the heat rate graph, which can be shown in Figure 7, and the formula can be seen as written in Equation (23) to Equation (26)

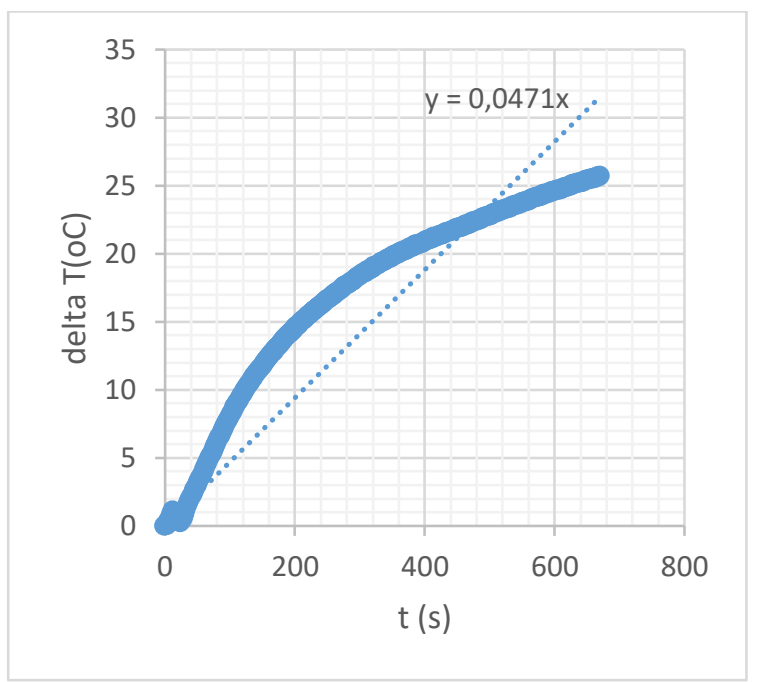

Figure 7. The relationship between time (seconds) to changes in temperature $\left({ }^{\circ} \mathrm{C}\right)$ in a waste solution.

The results of heat capacity and heat rate measurements can be determined as follows for the mass of the solution of $M_{g}=209$ grams, then the heat rate of $v$ is obtained from Figure 6 as written.

$$
\begin{aligned}
& v=M_{\text {grad }}=0,0471^{\circ} \mathrm{C} / \mathrm{s} \\
& I=2,4 \mathrm{~A} \\
& R=7.17 \Omega \\
& M_{g}=209 \mathrm{gram} \\
& C_{v}=4.19 \mathrm{Joule} / \mathrm{gr}^{\circ} \mathrm{C} \\
& M_{1}=\frac{\Delta T_{\text {final }}-\Delta T_{\text {initial }}}{t_{\text {final }}-t_{\text {initial }}} \\
& =\frac{25,69-0}{670-0} \\
& 0,0383^{\circ} \mathrm{C} / \mathrm{s} \\
& M_{2}=\frac{\Delta T_{\text {final }}-\Delta T_{\text {initial }}}{t_{\text {final }}-t_{\text {initial }}} \\
& =\frac{20-0}{360-0} \\
& =0,0555^{\circ} \mathrm{C} / \mathrm{s}
\end{aligned}
$$

$$
\begin{aligned}
\left|\Delta M_{\text {grad }}\right|= & \frac{\left|M_{1}-M_{\text {grad }}\right|+\left|M_{2}-M_{\text {grad }}\right|}{2} \\
=\frac{|0,0383-0,0471|+|0,0555-0,0471|}{2} & \\
= & \frac{|-0,0034|+|0,0138|}{2} \\
& =0,0086^{\circ} \frac{C}{s}
\end{aligned}
$$

$$
\begin{aligned}
& M_{\text {gradient }} \pm \Delta M_{\text {gradient }}=(0,0417 \pm 0,0086)^{\circ} \mathrm{C} / \mathrm{s} \\
& c_{v}=\frac{I^{2} R}{m \cdot M_{\text {grad }}} \\
& =\frac{(2,4)^{2} \cdot 7 \cdot 17}{209 \cdot 0,0471} \\
& =4.19 \mathrm{~J} / \mathrm{gram}^{\circ} \mathrm{C} \\
& \left|\Delta c_{v}\right|=\left|\frac{\partial c_{v}}{\partial M_{\text {grad }}} \cdot \Delta M_{\text {grad }}\right| \\
& =\left|\frac{\frac{I^{2} R}{m \cdot M_{\text {grad }}}}{M_{\text {grad }}} \cdot \Delta M_{\text {grad }}\right| \\
& =\left|\frac{I^{2} R}{m \cdot M_{\text {grad }}^{2}} \cdot \Delta M_{\text {grad }}\right| \\
& =\left|\frac{(2,4)^{2} \cdot(7,17)}{209 \cdot(0,0471)^{2}} \cdot 0,0086\right| \\
& =0,766 \mathrm{~J} / \mathrm{gram}^{\circ} \mathrm{C}
\end{aligned}
$$$$
(C v \pm \Delta C v)=(4,19 \pm 0,77) \mathrm{J} / \mathrm{gram}^{\circ} \mathrm{C}
$$

Table 1 shows the heat capacity of various types of waste solutions in textiles, especially dyeing waste.

Table 1. the specific heat of waste solution taken from dyeing laboratory.

\begin{tabular}{lc}
\hline Solution & $\mathbf{C v}\left(\mathrm{J} \mathbf{g r a m}^{\circ} \mathrm{C}\right)$ \\
\hline Green waste & $\mathbf{6 , 2 3} \pm \mathbf{0 , 6 1}$ \\
Orange waste & $\mathbf{5 , 6 8} \pm \mathbf{0 , 3 3}$ \\
Blue waste & $\mathbf{3 , 2 0} \pm \mathbf{0 , 7 2}$ \\
Brown waste & $\mathbf{6 , 8 3} \pm \mathbf{1 , 7 1}$ \\
Hard water & $\mathbf{4 , 1 9} \pm \mathbf{0 , 7 7}$ \\
\hline
\end{tabular}

According to (Hashim et al., 2017) the need for a real-time heat rate and heat specific measurement of the solution is to obtain a study of textile waste treatment methods so that the investigation regarding the EC method can be optimized. Based on the results of the study, it is found that water has a heat specific values as determined $\left(c_{v}\right.$ 
$\left.\pm \Delta c_{v}\right)=(4.19 \pm 0.77) \mathrm{J} / \mathrm{gram}^{\circ} \mathrm{C}$, while the highest heat specific is owned by brown waste that is equal to $\left(c_{v} \pm \Delta c_{v}\right)=(6.83 \pm$ 1.71) $\mathrm{J} / \mathrm{gram}^{\circ} \mathrm{C}$ and the lowest heat specific is blue waste which is $\left(c_{v} \pm \Delta c_{v}\right)=(3.20 \pm$ $0.72) \mathrm{J} / \mathrm{gram}^{\circ} \mathrm{C}$. Based on the results of the study, it has been found that the heating rate is inversely proportional to the heat capacity of a substance, and also the heat rate and the heat capacity of various textile wastes have been obtained along with the measurement method using an Arduino microcontroller.

Based on this research, it can be shown that the instrument can be used to measure the heat rate and heat capacity of a textile waste solution accurately by comparing the result of measurement by the literature of hard water as well as this device can be made easily by understanding the principle of microcontroller Arduino and also the thermodynamic theory. Based on this research, we have found that the specific heat of hard water $(4.19 \pm 0.77) \mathrm{J} /$ gram ${ }^{\circ} \mathrm{C}$ and the specific heat of the four types of waste solution ranged from $(3.20 \pm 0.72) \mathrm{J} /$ gram ${ }^{\circ} \mathrm{C}$ to $(6.83 \pm 1.71) \mathrm{J} /$ gram ${ }^{\circ} \mathrm{C}$ and also it was found that the heat rate of hard water is $0,0471^{\circ} \mathrm{C} / \mathrm{s}$ and the heat rate of the four types of waste solution is range from $0,0289^{\circ} \mathrm{C} / \mathrm{s}$ to $0,0617^{\circ} \mathrm{C} / \mathrm{s}$. In this research, the heat rate and the heat capacity of various textile wastes have been obtained along with the measurement method using a microcontroller. This research's significance is that a real-time measuring device for heat rate and heat capacity using a microcontroller can be implemented by academics and researchers to research in the field of environmental science and material physics studies, especially for wastewater in the textile dyeing.

\section{CONCLUSION}

In this research, the heat rate and the heat capacity of various textile wastes have been obtained along with the measurement method using an Arduino microcontroller. In this study, the heat capacity and heat rate measurement can be used to determine the heat capacity quite well.

\section{ACKNOWLEDGMENT}

The author would like to thank the Department of Textile Engineering Polytechnic STTT Bandung and the Physics Laboratory of Universitas Nusa Cendana for supporting this research activity so that this research can be completed well.

\section{AUTHOR CONTRIBUTIONS}

VG and EP collected and analyzed data. $\mathrm{JN}$ prepared literature in accordance with research. VG, EP and JN wrote the manuscript.

\section{REFERENCES}

Abdelhady, S. (2009). Thermodynamic analysis of electric charges and magnetic flux. 11th International Conference on Energy and Environment, (pp. 175-185). Ghurgada.

Ackermann, T. (1957). Hydration of $\mathrm{H}+$ and $\mathrm{OH}$-ions in water from heat capacity measurements. Discussions of the Faraday Society, 24, 180-193, https://doi.org/10.1039/DF95724001 80.

Amril, H. (2020). Teknologi plasma untuk pengolahan air. Bandung: Institut Teknologi Bandung.

Anwar, H., Santoso, H., Khameswara, T. D., \& Priantoro, A. U. (2017). MonitorPoP - ISP's PoP room temperature and humidity web based monitoring using microcontroller. Control and System Graduate Research Colloquium (ICSGRC) (pp. 212216.). IEEE.

Badamasi, Y. (2014). The working principle of an Arduino. International Conference on Electronics, computer and computation (pp. 1-4). Abuja, Nigeria:

IEEE. https://doi.org/10.1109/ICECCO.201 4.6997578.

Bramawanto, R., Triwibowo, H., \& Abida, 
R. F. (2019). Pemanfaatan teknologi mikrokontroler untuk pengukuran evaporasi suhu udara dan air pada produksi garam skala laboratorium. Jurnal Kelautan Nasional, 14(2), 155-164.

Biesheuvel, P. (2009). Thermodynamic cycle analysis for capacitive deionization. Journal of Colloid and Interface Science, 332(1), 258-264. https://doi.org/10.1016/j.jcis .2008.12.018.

Boltshauser, T., Leme, C., \& Baltes, H. (1993). High sensitivity CMOS humidity sensors with on-chip absolute capacitance measurement system. System Sensors and Actuators B: Chemical, 15(1-3), 7580. https://doi.org/10.1016/09254005(93)85 030-E.

Cengel, Y. A., \& Boles, M. A. (2010). Thermodynamics: An engineering approach, 7th Edition. New York: McGraw-Hill.

Cengel, Y. A., \& Boles, M. A. (2002). Thermodynamics: An engineering approach 4th Edition in SI Units. Singapore: McGraw-Hill.

Dean, R., \& Rane, A. (2013). A digital frequency-locked loop system for capacitance measurement. IEEE Transactions on Instrumentation and Measurement, 62(4), 777-784. https://doi.org/10.1109/TIM.2013.22 40092.

Dean, T., Bell, J., \& Baty, A. (1987). Soil moisture measurement by an improved capacitance technique, Part I. Sensor design and performance. Journal of Hydrology, 93(1-2), 6778. $\quad$ https://doi.org/10.1016/00221694(87)90194-6.

Desianna, I., Putri, C. A., \& Yulianti, I. (2017). Selulosa kulit jagung sebagai adsorben logam cromium $(\mathrm{Cr})$ pada limbah cair batik. Unnes Physics Journal, 6(1), 19-24.
Ditmars, D. (1988). Drop calorimetry above 300 K. London: Hemisphere Publishing Corporations.

Fadli, R. K., Riswanto, A. S., Aji, D., \& Widiasih, W. (2018). Aplikasi elektrokoagulasi untuk pengolahan limbah batik. Jurnal Abdikarya: Jurnal Karya Pengabdian Dosen Dan Mahasiswa, 1(2), 158-162.

Giwaa, S., Polatb, K., \& Hapoglua, H. (2012). The effects of operating parameters on temperature and electrode dissolution in electrocoagulation treatment of petrochemical. International Journal of Engineering Research and Technology (IJERT), 1(10), 2278.

Greiner, W., Neise, L., \& Stocker, H. (1995). Thermodynamics and statistical mechanics. New York: Springer.

Grolier, J., Benson, G., \& Picker, P. (1975). Simultaneous measurements of heat capacities and densities of organic liquid mixtures. Systems containing ketones. Journal of Chemical and Engineering Data, 20(3), 243-246. https://doi.org/10.1021/je60066a025.

Halliday, D., Resnick, R., \& Walker. (1997). Fundamenthal of Physics-Extended, 5th. New York: John Wiley\& Sons.

Hariyanto, M. W., Hendrawan, A. H., \& Ritzkal. (2020). Monitoring the environmental temperature. Journal of Robotics and Control (JRC), 1(3), 96-101, DOI: 10.18196/jrc.1321.

Hashim, K., Shaw, A., Khaddar, R. A., Pedrola, M. O., \& Phipps, D. (2017). Influence of electrodes spacing on internal temperature of electrocoagulation (EC) cells during the removal (Fe II) from drinking water. International Conference for Doctoral Research. Dubai: LJMU Research .

Hoffmann, T., Eilebrecht, B., \& Leonhardt, S. (2010). Respiratory monitoring system on the basis of capacitive textile force sensors. IEEE sensors 
journal, $\quad 11(5), \quad$ 1112-1119. https://doi.org/10.1109/

JSEN.2010.2082524.

Kodalkar, V., Ryu, G., Lee, Y., \& Lee, K. (2019). Development of highly sensitive and stable humidity sensor for real-time monitoring of dissolved moisture in transformer-insulating oil. Sensor and Actuators B: Chemical, 286(1), 377-385. https://doi.org/10.1016/j.snb.2019.01 .162 .

Mouedhen, G., feki, M., Wery, M., \& Ayedi, H. (2008). Behavior of aluminum electrodes in electrocoagulation process. journal of Hazardous Materials, 150(1), 124-135.

https://doi.org/10.1016/j.jhazmat.200 7.04.090.

Picker, P., Ledue, P., Philip, P., \& Desnoyers, J. (1971). Heat capacity of solutions by flow microcalorimetry. The Journal of Chemical Thermodynamics, 3(5), 631. https://doi.org/10.1016/S00219614(71)80084-8.

Pogatscher, S., Leutenegger, D., Hagmann, A., Uggowitzer, P. J., \& Loffler, J. F. (2014). Characterization of bulk metallic glasses via fast differential scanning calorimetry. Thermochim. Acta , 590(20), 84-90.

Pogatscher, S., Leutenegger, D., Schawe, J. E., Uggowitzer, P. J., \& Löffler, J. F. (2016). Solid-solid phase transitions via melting in metals. Nature Communication, doi:10.1038/ncomms11113. ISSN 2041-1723. PMC 4844691.

Putra, V. G., Mohamad, J. N., \& Yusuf, Y. (2020). Penerapan gelombang plasma dalam mengurangi kadar chemical oxygen demand (COD) pada limbah batik melalui corona plasma dan elektrokoagulasi dengan metode variasi. Jurnal Ilmu Fisika (JIF), $\quad$ 11(2), $\quad$ 60-69. https://doi.org/10.25077/jif.12.2.6069.2020.

Putra, V. (2017). Pengantar fisika dasar. Yogyakarta: CV. Mulia Jaya Publisher.

Putra, V., \& Purnomosari, E. (2015). Pengantar eksperimen fisika. CV. Mulia Jaya, ISBN 978.602.72713.0.2.

Putra, V., \& Wijayono, A. (2019). Suatu studi awal modifikasi sifat pembasahan pada permukaan kain tekstil poliester $100 \%$ menggunakan teknologi plasma pijar korona. EJournal Prosiding Seminar Nasional Fisika https://doi.org/10.21009/03.SNF201 9.02.PA.03.

Putra, V., Ngadiyono, N., \& Purnomosari, E. (2019). Pengantar praktikum mekatronika tekstil. Yogyakarta: CV. Mulia Jaya Publisher.

Putra, V., Purnomosari, E., \& Ngadiyono, N. (2016). Pengantar listrik magnet dan terapannya. Yogyakarta: CV. Mulia Jaya, ISBN 978-60272713-26-1.

Putra, V., Wijayono, A., Purnomosari, E., \& Irwan. (2019). Studi penentuan kalor jenis air dan larutan garam menggunakan mikrokontroler arduino uno. JIPFRI (Jurnal Inovasi pendidikan Fisika dan Riset Ilmiah), $3(2)$, 86. https://doi.org/10.30599/jipfri.v3i2.4 62.

Putra, V. G. V., Fitri, A. D., Purnama, I., \& Mohamad, J. N. (2020). Prototipe pakaian anti radiasi unisex sportswear smartphone dengan paparan radiasi plasma pijar korona elektroda tip- silinder. Jurnal Kumparan Fisika, 3(1), 19-24. https://doi.org/10.33369/jkf.3.1.1924

Quick, C. R., Schawe, J. E., Uggowitzer, P. J., \& Pogatscher, S. (2019). "Measurement of specific heat capacity via fast scanning 
calorimetry-Accuracy and loss corrections". Thermochimica Acta, 677, 12-20.

Rahardjo, D., Utami, W. B., Saputro, D., \& Jamaluddin, A. (2018). Design of calorimeters based on arduino mega. International Conference on Science and Applied Science (ICSAS) 2018 (pp. 1-6). AIP Conference Proceedings.

Raine, H., Richards, R., \& Ryder, H. (1945). The heat capacity, heat of solution, and crystallinity of polythene. Transactions of the faraday Society, 41, 56-64. https://doi.org/10.1039/TF94541000 56.

Rerkratn, A., \& Kaewpoonsuk, A. (2015). ZigBee based wireless temperature monitoring system for shrimp farm. International Conference on Control, Automation and Systems (pp. 428-431). IEEE.

Ridantami, V., Wasito, B., \& Prayitno. (2016). Pengaruh tegangan dan waktu pada pengolahan limbah radioaktif uranium dan torium dengan proses elektrokoagulasi. Jurnal Forum Nuklir (JFN), 10(2), 102-107.

Rusydi, A. F., Suherman, D., \& Sumawijaya, N. (2017). Pengolahan air limbah tekstil melalui proses koagulasi - flokulasi dengan menggunakan lempung sebagai penyumbang partikel tersuspensi. Arena Tekstil, 31(2). https://doi.org/10.31266/at.v31i2.167 1

Said, N. I. (2002). Pengolahan air limbah industri kecil tekstil dengan proses biofilter anaerob-aerob tercelup menggunakan media plastik sarang tawon. Jurnal Teknologi Lingkungan, 2(2), 124-135.

Salvo, P., Francesko, F., Costanzo, D., ferrari, C., Trivella, M., \& Rossi, D. (2010). A wearable sensor for measuring sweat rate. IEEE Sensors
Journal, $\quad 10(10), \quad$ 1557-1558. https://doi.org/10.1109/JSEN.2010.2 046634.

Sathian, S., Rajasimman, M., Rathnasabapathy, C., \& Karthikeyan, C. (2014). Performance evaluation of SBR for the treatment of dyeing wastewater by simultaneous biological and adsorption. Journal of Water Process Engineering, 4, 8290.

https://doi.org/10.1016/j.jwpe.2014.0 9.004.

Schick, C., \& Mathot, V. (2016). Fast scanning calorimetry. London: Springer. 10.1007/978-3-319-313290 .

Simoes-Moreira, J. (2010). An air-standard cycle and a thermodynamic perspective on operational limits of Ranque-Hilsh or vortex tubes. International Journal of refrigerator, 33(4), 765-773. https://doi.org/10.1016/j.ijrefrig.201 0.01 .005 .

Sreejith, K., Shyamkumar, P., Appu, R., \& Sreedevi, C. (2015). A low cost automated specified heat capacity meter for liquids. International Conference on Trends in Automation, Communications and Computing Technology (I-TACT-15 (pp. 1-4). IEEE. https://doi.org/10.1109/ITACT.2015. 7492691.

Suherman, Andriyanto, I., \& Dwiyatno, S. (2015). Rancang bangun alat ukur temperatur suhu perangkat server menggunakan sensor LM35 berbasis SMS Gateway. Jurnal Prosisko, 2(1), 42-63.

Teruel, J. G., Sanchez, R. T., Ros, P. B., Moreo, A. T., Buendia, M. M., \& Valles, F. S. (2019). Design and calibration of a low-cost SDI-12 soil moisture sensor. Sensors, 19(3), 491. https://doi.org/10.3390/s19030491.

Thomas, D., Zhuravlev, E., Wurm, A., Schick, C., \& Cebe, P. (2018). 
Fundamental thermal properties of polyvinyl alcohol by fast scanning calorimetry. Polymer, 1, 145-155.

Tirono, M., \& Sabit, A. (2012). Efek suhu pada proses pengarangan terhadap nilai kalor arang tempurung kelapa (coconut shell charcoal). Journal Neutrino: Jurnal Fisika dan Aplikasinya, 3(2). http://dx.doi.org/10.18860/neu.v0i0. 1647.

Ulesova, A., Grechko, A., \& Sadova, S. (2008). Continuous dyeing of wool fabric containing polyamide fibre and modified by plasma glow discharge. Fibre Chemistry, 40, 143146. https://doi.org/10.1007/s10692008-9027-4.

Wakida, T., Cho, S., Choi, S., Tokino, S., \& Lee, M. (1998). Effect of low temperature plasma treatment on color of wool and nylon 6 fabrics dyed with natural dyes. Textile Research Journal, 68(16), 848-853. https://doi.org/10.1177\%2F0040517 59806801110.

Wakida, T., Tokino, S., Niu, S., Lee, M., Uchiyama, H., \& Kaneko, M. (1993). Dyeing properties of wool treated with low-temperature plasma under atmospheric pressure. Textile Research Journal, 438-442. https://doi.org/10.1177\%2F0040517 59306300802.

Yilmaz, A., Boncukcuoglu, R., Kocakerim, M., Yilmaz, M., \& Paluluoglu, C. (2008). Boron removal from geothermal waters by electrocoagulation. Journal of Hazardous Materials, 153(1-2), 146151.

https://doi.org/10.1016/j.jhazmat.200 7.08.030.

Yumang, A. N., Paglinawan, C. C., Sejera, M. M., Lazam, A. S., Pagtakhan, J., \& Santos, J. S. (2016). ZigBee based monitoring of temperature and humidity of server rooms using thermal imaging. 6th IEEE International Conference on Control System, Computing and Engineering (ICCSCE) (pp. 452-454). IEEE.

Zhuravlev, E., \& Schick, C. (2010). Fast scanning power compensated differential scanning nanocalorimeter: 1 . The device. Thermochim. Acta, 505(1-2), 1-13. 